\title{
MODEL MATEMATIKA HUBUNGAN BOBOT TUBUH DENGAN UKURAN FLIPPER TUKIK PENYU LEKANG YANG DIBERI PAKAN IKAN TUNA VERSUS UDANG DALAM BENTUK PELLET SAMPAI UMUR TIGA BULAN
}

\author{
I KETUT SUKADA DAN ANDI UDIN SARANSI \\ FAKULTAS PETERNAKAN UNIVERSITAS UDAYANA \\ JL. PB SUDIRMAN, DENPASAR, BALI \\ Email: ketut_sukada@yahoo.com
}

\begin{abstract}
ABSTRAK
Penelitian ini bertujuan untuk mencari hubungan bobot tubuh dengan lebar flippers depan dan flipper belakang sebagai alat untuk berenang dan menyelam. Penelitian dilaksanakan selama 12 minggu menggunakan Rancangan Acak Lengkap yang dianalisis dengan Analisis Variant. Perlakuan A: ikan tuna 100\%, B: ikan tuna $75 \%$ udang 25\%, C: ikan tuna 50\% udang 50\%, D: ikan tuna 25\% udang 25\% dan E udang 100\%. Perlakuan diulang 5 kali dan setiap ulangan diulang 3 kali sehingga tukik yang digunakan sebanyak 75 ekor. Hasil penelitian: Bobot tubuh menunjukkan perbedaan yang sangat nyata $(\mathrm{P}<0,01)$ dengan urutan:Perlakuan A; 80,3040 g. B; 76,2580 g. C; 66,6720 g. D; 63,2020 g. E; 57,8240 g. Lebar pliffes depan menunjukkan perbedaan yang nyata $(P<0,05)$ dengan urutan masing-masing perlakuan adalah : $\mathrm{B} ; 1,8000 \mathrm{~cm} . \mathrm{C} ; 1,8500 \mathrm{~cm}$. A; $1,8000 \mathrm{~cm} . \mathrm{D} ; 1,7700 \mathrm{~cm}$. dan E; $1,6000 \mathrm{~cm}$. Berat pliffes depan menunjukkan perbedaan yang sangat nyata $(\mathrm{P}<0,01)$ dengan urutan masingmasing perlakuan adalah : A; 14,7550 g. B; 14,5350 g. C; 12,6950 g. D; 10,3950 g. dan E; 8,8600 g. Korelasi bobot tubuh terhadap lebar flippers depan $\mathrm{Y}=7,0830530 \mathrm{e}^{1,1436892 \times} \mathrm{R}^{2}=0,738308491$. Kandungan protein dari masingmasing perlakuan A; 22\%, B; 20\%, C; 19\%, D; 18\% dan E; 17\%. Retensi protein dan retensi energi tukik yang diberi perlakuan A nyata lebih tinggi ( $\mathrm{P}<0,05)$ yaitu RP; 77,9765 $(\%), \mathrm{RE} ; 75,7464^{\mathrm{a}} \%$ dibandingkan retensi protein dan retensi energi tukik yang diberikan perlakuan E yaitu RP; 45,1076 (\%), RE; 43,4060 \%. Pada kesimpulannya respon pertumbuhan tukik penyu lekang yang diberi pakan ikan tuna lebih banyak dibandingkan udang lebih baik.
\end{abstract}

Kata kunci : model matematika, bobot tubuh, flipper, tukik penyu lekang

\section{MATH MODEL OF LEKANG JUVENILES BODY WEIGHT RELATIONSHIP WITH FLIPPERS SIZE FED TUNA VS SHRIMP (FORMED IN PELLET UP TO THREE MONTHS OF AGE}

\begin{abstract}
This study was carried out to find the relationship of front and back flippers width as their function for swimming and diving. The study was analyzed with Variant Analysis in a Completely Randomized Design for 12 weeks. The treatments were (A) 100\% tuna fish; (B) 75\% tuna fish and 25\% shrimp; (C) 50\% tuna fish and 50\% shrimp; (D) $25 \%$ tuna fish, $25 \%$ shrimp; and (E) 100\% shrimp. Those treatments were repeated 5 times with 5 replications, and each replication repeated 3 times using 75 juveniles. The study showed highly significant differences of body weight (P<0.01) in treatments, as of: (A) 80.3040 g. ; (B) 76.2580 g. ; (C) 66.6720 g. ; (D) 63.2020; (E) 57.8240 g., respectively. There were significant differences on the front flippers $(\mathrm{P}<0.05)$, such as: (B) $1.8000 \mathrm{~cm}$. ; (C) $1.8500 \mathrm{~cm}$.; (A) $1.8000 \mathrm{~cm}$.; (D) $1.7700 \mathrm{~cm}$.; and (E) $1.6000 \mathrm{~cm}$. Front flippers size showed significant differences (P<0.01) in treatments, as follows: (A) 14.7550 g. ; (B) 14.5350 g. ; (C) 12.6950 ; (D) 10.3950 g. ; and (E) 8.8600 g. Body weight correlation to front flippers width was $\mathrm{Y}=7.0830530 \mathrm{e}^{1.1436892 \times} \mathrm{R}^{2}=0.738308491$. Each treatment containing protein content, such as: (A) 22\%; (B) 20\%; (C) 19\%; (D) 18\%; and (E) 17\%. Protein retention and energy retention of juveniles in A treatment showed significantly higher $(\mathrm{P}<0.05)$ as of: (RP) $77.9765^{\mathrm{a}} \%$; (RE) $75.7464^{\mathrm{a}} \%$ compared to protein retention and energy retention of juveniles in E treatment e.g. (RP) 45.1076 \%; (RE) 43.4060 e \%. It can be concluded that growth response of lekang juveniles fed with tuna fish were better than shrimp.
\end{abstract}

Keywords: math model, body weight, flippers, and lekang juveniles 
and Lane, 1964). Menurut Soeparno (1992), pertumbuhan termasuk proses yang kompleks yang tidak dapat didefinisikan secara sederhana, karena tidak hanya meliputi peningkatan ukuran saja tetapi juga merupakan peningkatan bobot tubuh (bobot hidup), komposisi tubuh, termasuk perubahan komponen-komponen tubuh seperti otot, tulang dan organ-organ lainnya. Kimball (1990) menyatakan bahwa dari segi biologi, pertumbuhan merupakan suatu proses seluler dimana terjadi peningkatan jumlah sel, penambahan ukuran sel dan substansi interseluler. Sel-sel yang bertambah besar itu setelah ukuran maksimum tercapai tidak akan bertambah besar lagi dan pertumbuhan terhenti atau terjadi pembelahan sel. Menurut Campbell dan Lasley (1975), dari sudut kimiawi pertumbuhan merupakan penambahan jumlah protein dan zat-zat mineral yang diakumulasikan dalam tubuh.

\section{Konsumsi Pakan}

Pada akhir penelitian didapaknat bahwa tukik yang diberi perlakuan pakan yang mengandung ikan tuna lebih banyak dari udang memberikan konsumsi pakan tidak berbeda nyata $(\mathrm{P}>0,05)$ dibandingkan tukik yang diberi perlakuan pakan mengandung ikan tuna lebih sedikit dari udang. Konsumsi pakan, masing-masing perlakuan yang diberikan pada akhir penelitian yaitu: perlakuan A: 95,3026 g, B: 95, 2057 g, C: 96,2255 g, D: 95,5749 g dan E: 96,6504. Pada akhir penelitian terlihat sangat jelas pada grafik, masing-masing perlakuan mengarah ke satu garis karena semua perlakuan tidak berbeda nyata. Semua garis masing-masing perlakuan berimpit mengarah ke angka $100 \mathrm{~g}$.

Konsumsi pakan tukik penyu lekang yang diberikan masing-masing perlakuan disajikan pada Gambar 2

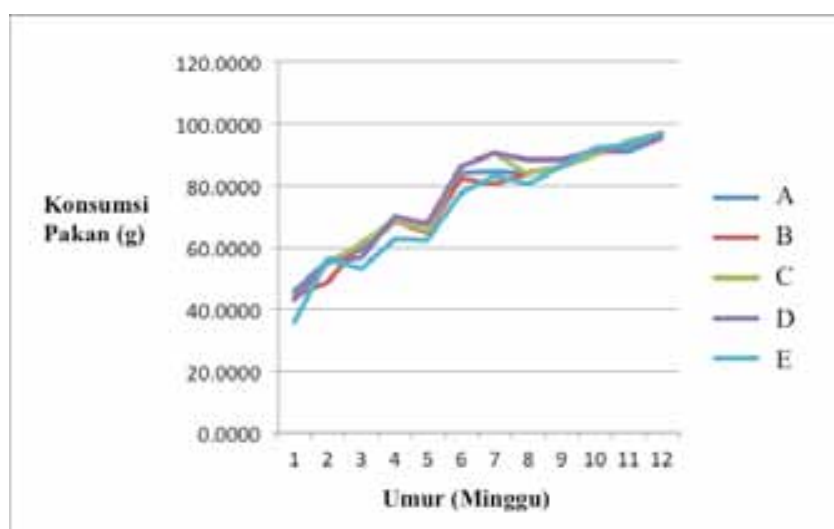

Gambar 2 Konsumsi pakan tukik penyu lekang sampai minggu ke 12

\section{FCR (Feed Conversion Ratio)}

Feed Conversion Ratio merupakan perbandingan antara pakan yang dikonsumsi dengan tambahan bobot tubuh yang dicapai. Makin kecil FCR maka makin efisien hewan itu menggunakan pakan. Feed Conversion Ratio tukik yang diberikan perlakuan E menunjukkan konsumsi pakan yang paling tidak efisien. Hal ini diakibatkan karena bobot tubuh yang dicapai oleh tukik yang diberikan perlakuan E pada akhir penelitian paling rendah $(\mathrm{P}<0,05)$, sedangkan konsumsi pakan semua perlakuan pada akhir penelitian tidak berbeda nyata $(\mathrm{P}>0,05)$. Urutan FCR yang dicapai tukik penyu lekang yang diberikan masing-masing perlakuan yaitu: perlakuan E: 2,1724; D: 1,9165; C: 1,7951; B: 1,5146; A: 1,4579. Tabel 5.1 menampilkan tambahan bobot tubuh dan konsumsi pakan pada akhir penelitian yang menentukan efisiensi penggunaan pakan. Feed conversion ratio tukik yang diberikan perlakuan $\mathrm{E}$ paling tidak efisien, diakibatkan karena pertambahan bobot tubuh tukik yang diberikan perlakuan $\mathrm{E}$ paling rendah.

\section{Retensi Protein dan Retensi Energi}

Retensi protein pada tukik yang diberikan perlakuan A berbeda nyata lebih tinggi dari $\mathrm{B}(\mathrm{P}<0,05)$, berbeda sangat nyata lebih tinggi dari $\mathrm{C}, \mathrm{D}$ dan $\mathrm{E}(\mathrm{P}<\mathrm{O}, 01)$. Perlakuan $\mathrm{B}$ berbeda nyata lebih tinggi dengan $\mathrm{C}(\mathrm{P}<0,05)$, berbeda sangat nyata lebih tinggi dengan perlakuan $\mathrm{D}$ dan $\mathrm{E}(\mathrm{P}<\mathrm{O}, 01)$. Perlakuan $\mathrm{C}$ berbeda nyata lebih tinggi dengan $\mathrm{D}(\mathrm{P}<0,05)$, berbeda sangat nyata lebih tinggi $\mathrm{E}(\mathrm{P}<\mathrm{O}, 01)$, sedangkan tukik yang diberikan perlakuan $\mathrm{D}$ berbeda nyata lebih tinggi dengan perlakuan $\mathrm{E}$ $(\mathrm{P}<0,05)$. Dapat dinyatakan bahwa peningkatan retensi protein seiring dengan peningkatan ikan tuna dalam pakan yaitu ikan tuna paling banyak diberikan pada perlakuan A (RP: 77,9765\% \%) dan palaing sedikit pada perlakuan E (45,1076 \%). Hal ini disebabkan karena protein ikan tuna lebih tinggi dibandingkan protein udang. Serat kasar ikan tuna lebih rendah dibandingkan serat kasar udang. Protein kasar ikan tuna hasil proksimate analisis pada penelitian ini PK: 22,0000 \% dan serat kasar SK: 0,2971\%. Protein kasar udang PK: 17,8679\% dan serat kasar SK: 0,4372\%.

Retensi energi tukik yang diberikan perlakuan A paling tinggi, berbeda nyata dengan perlakuan B dan C $(\mathrm{P}<0,05)$, berbeda sangat nyata dengan perlakuan $\mathrm{D}$ dan E. Retensi energi tukik yang diberikan perlakuan B dan $\mathrm{C}$ berbeda nyata dengan perlakuan $\mathrm{D}$ dan $\mathrm{E}(\mathrm{P}<0,05)$, sedangkan retensi energi tukik yang diberikan perlakuan $\mathrm{D}$ berbeda nyata dengan perlakuan $\mathrm{E}(\mathrm{P}<0,05)$. Hal ini hampir sama dengan retensi protein. Retensi energi tukik penyu lekang yang diberikan ikan tuna lebih banyak lebih tinggi dibandingkan diberikan ikan tuna lebih sedikit. Energi bruto ikan tuna hasil proksimate analisis pada penelitian ini GE: 1,2797 k.kal. sedangkan energi bruto udang GE: 1,1443 k.kal. 


\section{PENDAHULUAN}

Penurunan populasi penyu lekang hampir terjadi di seluruh negara-negara di dunia yang memiliki pantai dan perairan.(Polunin, 1975; Aureggi et al., 2004; Cornelius et al., 2007; Gaos et al., 2006; Godfrey dan Chevalier, 2004; Frazier et al, 2007; Plotkin, 2008; Pandav et al, 1994).

Kematian penyu terbesar adalah mulai dari telur dan menetas menjadi tukik (Gaos et al, 2006). Tukik yang baru menetas langsung dilepas kehabitatnya mudah terserang predator. Tukik sebaiknya dipelihara selama 3 bulan terlebih dahulu sebelum dilepas ke habitatnya, diberikan pakan ikan tuna dan udang untuk memenuhi kebutuhan nutrisi sehingga mencapai pertumbuhan yang ideal. Respon bobot tubuh dan ukuran flippers yang diakibatkan oleh pakan ikan tuna dan udang perlu diketahui karena flipper sangat menentukan kelincahan, kecepatan dan kegesitan tukik berenang dan menyelam mencari makan dan menghindarkan diri dar serangan predator (Nuitja, 1997; Chung et al., 2009).

Penelitian ini bertujuan untuk mencari korelasi antara bobot tubuh terhadap ukuran flippers tukik penyu lekang umur tiga bulan.

\section{MATERI DAN METODE}

Penelitian ini menggunakan tukik penyu lekang hasil penetasan dari relokasi pengeraman, sebanyak 75 ekor dengan berat berkisar 13,33 g $\pm 0,7489 \mathrm{~g}$. Tukik sampai umur 3 hari diberikan pakan 50\% ikan tuna dan 50\% udang, selanjutnya setelah tukik berumur seminggu baru diberikan perlakuan. Penelitian menggunakan Rancangan Acak Lengkap (RAL) Gomez dan. Gomez (1995) menggunakan 5 perlakuan A; 100\% ikan tuna o\% udang, B; 75\% ikan tuna 25\% udang, C; 50\% ikan tuna 50\% udang, D; 25\% ikan tuna 75\% udang dan E; o\% ikan tuna 100\% udang. Perlakuan diulang lima kali dan masing-masing ulangan menggunakan tiga sub unit ulangan. Pakan merupakan recahan daging ikan tuna dan udang yang dibekukan, dibuat dalam bentuk pellet berdiameter kurang lebih $1 \mathrm{~cm}$. Pakan diberikan secara adlibitum satu kali sehari setiap pagi hari. Pakan diberikan pada ember plastik yang terpisah dengan ember tempat pemeliharaan. Sehabis makan sisa makanan diukur dan tukik dipindahkan ke tempat pemeliharaan. Pergantian air dilakukan setiap 2 hari sekali sambil mengambil feses melalui saringan yang terbuat dari kain kasa sehingga air laut tetap jernih. Variabel yang diukur meliputi jumlah pakan, bobot feses dan respon pertumbuhan yaitu bobot tubuh, ukuran karapak, ukuran plastron, ukuran pliffer Data dianalisis dengan analisa variant dan uji lanjut menggunakan Duncant (Steel dan Torrie, 1980). Untuk membuat model hubungan antara bobot tubuh terhadap ukuran flippers digunakan analisis exponensial. Data hasil penelitian diolah menggunakan Costat.

\section{Komposisi Nutrisi Pakan}

Susunan dan Komposisi Nutrisi Pakan Perlakuan Tukik Penyu Lekang disajikan pada Tabel.1.

\begin{tabular}{|c|c|c|c|c|c|}
\hline \multirow{2}{*}{$\begin{array}{c}\text { Variabel } \\
\text { Susunan Pakan }\end{array}$} & \multicolumn{5}{|c|}{ Perlakuan } \\
\hline & $A$ & $B$ & $\mathrm{C}$ & $\mathrm{D}$ & $E$ \\
\hline Ikan (\%) & 100 & 75 & 50 & 25 & 0 \\
\hline Udang (\%) & 0 & 25 & 50 & 75 & 100 \\
\hline \multicolumn{6}{|l|}{ Komposisi } \\
\hline BK (\%) & 28,7393 & 26,4563 & 26,7742 & 25,9841 & 22,7809 \\
\hline Abu (\%) & 2,7298 & 1,4973 & 1,3982 & 1,8233 & 1,8854 \\
\hline PK (\%) & 22,0000 & 20,8916 & 19,9215 & 18,3705 & 17,8679 \\
\hline CF (\%) & 0,2971 & 0,2749 & 0,2755 & 0,7978 & 0,4372 \\
\hline L (\%) & 1,3998 & 0,9688 & 1,2393 & 1,2806 & 1,0721 \\
\hline $\mathrm{EB}$ (k.kal) & 1,2797 & 1,2380 & 1,2652 & 1,2722 & 1,1443 \\
\hline
\end{tabular}

\section{HASIL DAN PEMBAHASAN}

\section{Bobot Tubuh Tukik Penyu Lekang}

Pada akhir penelitian didapatkan bahwa tukik yang diberi perlakuan pakan yang mengandung ikan tuna lebih banyak dari udang memberikan pertumbuhan yang lebih baik dibandingkan tukik yang diberi perlakuan pakan mengandung ikan tuna lebih sedikit dari udang. Hasil penelitian menunjukkan bahwa tukik penyu lekang yang diberi perlakuan A (ikan tuna 100\%) mencapai bobot tubuh paling tinggi yaitu: $80,3040 \mathrm{~g}$ dibandingkan dengan tukik yang diberikan perlakuan E (udang 100\%) mencapai bobot tubuh paling rendah yaitu: 57,8240 g $(\mathrm{P}<0,05)$. Hal ini disebabkan karena ikan tuna mengandung protein kasar $22 \%$, energy bruto $1,27 \mathrm{k} . \mathrm{kal}$, sedangkan udang mengandung protein kasar $17,8679 \%$, energy bruto 1,14k.kal. Bobot tubuh tuki penyu lekang disajikan pada Gambar. 1

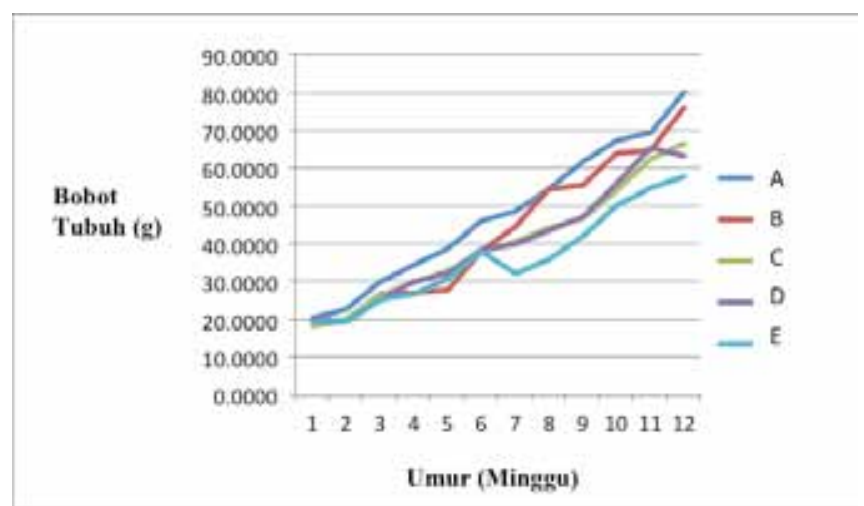

Gambar 1 Grafik Bobot tubuh Tukik Penyu Lekang

Pertumbuhan adalah penambahan ukuran otot, organ dalam dan bagian-bagian tubuh lainnya (Guyer 


\section{Model Matematika Hubungan Berat Tubuh de- ngan Ukuran Flipper}

Korelasi antar pertumbuhan organ tubuh secara biologi tukik penyu lekang yang diberikan pakan ikan tuna dan udang dianalisis dengan regresi exponensial menggunakan pengolahan data dengan cara Costat. Korelasi respon pertumbuhan antara tubuh tukik penyu lekang secara biologi yang diamati dalam penelitian ini lebih ditekankan pada korelasi respon pertumbuhan antara bobot tubuh terhadap ukuran flippers. Nilai korelasi antar respon pertumbuhan organ tubuh secara biologi dicerminkan oleh nilai $\mathrm{R}^{2}$.Semakin besar $\mathrm{R}^{2}$ hubungan semakin signifikan dan semakin erat. Model persamaan matematis yang ditemukan dapat digunakan untuk meramal bobot tubuh tukik penyu lekang umur 3 bulan melalui ukuran flippersnya. Korelasi antara berat badan terhadap ukuran flippers ternyata yang paling baik adalah korelasi antara bobot tubuh terhadap lebar flipper depan dan korelasi antara bobot tubuh terhadap berat flippers belakang. Flippers yang berfungsi sebagai dayung dan kemudi sangat menentukan kecepatan dan kelincahan tukik berenang dan menyelam untuk menghindarkan diri dari serangan predator ((Nuitja, 1997; Chung et al., 2009). Korelasi antara bobot tubuh terhadap ukuran flippers disajikan pada Tabel. 2

\begin{tabular}{|c|c|c|}
\hline Variabel & Persamaan Regresi & $\mathrm{R}^{2}$ \\
\hline $\begin{array}{l}\text { Bobot tubuh x Panjang flippers } \\
\text { depan }\end{array}$ & $Y=18,732624 \mathrm{e}^{0,1460593 x}$ & 0,491316403 \\
\hline $\begin{array}{l}\text { Bobot tubuh x Lebar flippers } \\
\text { depan }\end{array}$ & $Y=7,0830530 e^{1,1436892 x}$ & 0,738308491 \\
\hline $\begin{array}{l}\text { Bobot tubuh x Berat flippers } \\
\text { depan }\end{array}$ & $Y=30,250207 e^{0,0476874 x}$ & 0,743784351 \\
\hline $\begin{array}{l}\text { Bobot tubuh x Panjang flippers } \\
\text { belakang }\end{array}$ & $Y=23,872547 e^{0,2059847 x}$ & 0,241922828 \\
\hline $\begin{array}{l}\text { Bobot tubuh x Lebar flippers } \\
\text { belakang }\end{array}$ & $Y=29,935639 e^{0,3378002 x}$ & 0,101395199 \\
\hline $\begin{array}{l}\text { Bobot tubuh x Berat flippers } \\
\text { belakang }\end{array}$ & $Y=24,123957 e^{0,1329788 x}$ & 0,854935651 \\
\hline
\end{tabular}

Pertumbuhan merupakan penambahan ukuran otot, organ dalam dan bagian-bagian tubuh lainnya (Guyer \& Lane, 1964). Menurut Soeparno (1992), pertumbuhan tidak hanya meliputi peningkatan ukuran tubuh saja tetapi juga merupakan peningkatan bobot tubuh (bobot hidup), komposisi tubuh, termasuk perubahan komponen-komponen tubuh seperti otot, tulang dan organ-organ lainnya. Kimball (1990) menyatakan bahwa dari segi biologi, pertumbuhan merupakan suatu proses seluler dimana terjadi peningkatan jumlah sel, penambahan ukuran sel dan substansi interseluler. Setelah ukuran maksimum tercapai sel-sel tubuh tidak akan bertambah besar lagi dan pertumbuhan terhenti atau terjadi pembelahan sel. Menurut Campbell dan Lasley (1975), dari sudut kimiawi pertumbuhan merupakan penambahan jumlah protein dan zat-zat mineral yang diakumulasikan dalam tubuh. Peningkatan bobot tubuh selama pertumbuhan terutama disebabkan oleh peningkatan akumulasi protein tubuh (Sturkie, 1976). Penambahan bobot tubuh ini biasanya digunakan sebagai parameter pertumbuhan (Maynard dan Loosli, 1969), sedangkan menurut Williamson \& Payne (1993), indicator pertumbuhan itu berupa peningkatan bobot tubuh per satuan waktu. Brody (1985) dalam Soeparno (1992) menyatakan bahwa pertumbuhan hewan didasarkan pada kenaikan berat tubuh per satuan waktu tertentu. Pond dan Manner (1974) menyatakan bahwa laju pertumbuhan dihitung dari pengurangan bobot tubuh akhir dengan bobot tubuh awal dibagi lamanya waktu pengamatan.

\section{KESIMPULAN}

1. Respon pertumbuhan tukik penyu lekang yang diberi pakan sampai umur 3 bulan dapat disimpulkan bahwa pertumbuhan tukik yang diberikan pakan ikan tuna yang lebih banyak dari udang lebih baik dibandingkan tukik yang diberikan pakan ikan tuna lebih sedikit dari udang.

2. Model matematika hubungan antara bobot tubuh terhadap ukuran flippers depan dan flippers belakang khususnya bobot tubuh terhadap lebar flipper depan dapat disimpulkan $\mathrm{Y}=7,0830530 \mathrm{e}^{1,1436892 \times} \mathrm{R}^{2}$ $=0,738308491$ dan antara bobot tubuh terhadap berat flipper belakang $\mathrm{Y}=24,123957 \mathrm{e}^{0,1329788 \times} \mathrm{R}^{2}=$ 0,854935651

\section{SARAN}

Untuk mendapatkan Respon pertumbuhan tukik penyu lekang yang baik sebaiknya tukik diberikan pakan ikan tuna yang lebih banyak dari udang lebih dan untuk menduga respon pertumbuhan bobot tubuh tukik penyu lekang umur 3 bulan yang diberikan pakan ikan tuna dan udang sebaiknya menggunakan lebar flipper depan dengan persamaan matematis $\mathrm{Y}=7,0830530$ $\mathrm{e}^{1,1436892 \mathrm{x}}$

\section{KEPUSTAKAAN}

Campbell, J. R., and Lesley, J. F.. 1975. The Science of Animal That Serve Mankind. Tata McGraw-Hill Publishing Company Limited. New Delhi

Chung, CF.NJpilcher, Salmon , M.,and Wyneken, J. 2009. Frenzy and post frenzy eretmochelys imbricate swimming speed and comparative morphology chelonian conservation

Cornelius, S.E., Arauz, R., Fretey, J., Godfrey, M.H., Márquez, M.R., and Shanker, R.K.. 2007. Effect of land-based harvest of Lepidochelys . In: PT Plotkin (ed.), Biology and Conservation of Ridley Sea Turtles, Johns Hopkins University Press, Baltimore, MD. 
Frazier, J., Aruaz, R., Chevalier, J., Formia, A., Fretey, J., Godfrey, M.H., Marquez, M.R., Pandav B., and Shankar, K. 2007. Biology and conservation of ridley sea turtles. John Hopkins University Press, Baltimore. pp. 253-296

Gaos, AR., Yañez, I.L., and Arauz, R.M. 2006. Sea turtle conservation and research on the Pacific coast of Costa Rica. Technical Report. Laporan Teknis. Programa Restauración de Tortugas Marinas.

Gomez, R. A. and Gomez, A. A. 1984. Statistical Procedures For Agricultural Research. Second Edition. John Wiley \& Sons. NewYork.

Guyer, M. F. and Lane, C. R. 1964. Animal Biology. Herper and Row Publishers London

Kimball, F. W. 1990. Buku Biologi Penerbit Erlangga Jakarta

Maynard, L. A. and Loosli, J. A. 1969. Animal Nutrition. Seventh Edition. Tata Mc Graw-Hill Publishing Co. Ltd. Bombay. New Delhi.

Nuitja, I.N.S. 1997. Biologi dan Ekologi Pelestarian Penyu Laut. Institut Pertanian Bogor. Bogor Jawa Barat.

Pandav, B., and Choudhury, B.C. 2006. Migration and movement of Olive Ridley Turtles along the east coast of India. Pp. 365-379 In Marine Turtles of the Indian Subcontinent. Choudhury, B.C. and K. Shanker (Eds.). Universities Press, Hyderabad, AP,India

Plotkin, P.T. 1989. Feeding ecology of the loggerhead sea turtle in the northwestern Gulf of Mexico. Pp. 139-141. In S.A. Eckert, K.L. Eckert and T.H. Richardson (compilers). Proceedings of the Ninth Annual Workshop on Sea Turtle Conservationand Biology. NOAA Tech. Memo. NMFS-SEFC-232. U.S. Dept. Commerce,Miami, FL. P. 305

Pond, W. G. , and Manner, J. H. 1974. Swine Production in Temperate and Tropical Environments. W. H. Freeman and Co. NewYork.

Steel, R.G.D., and Torrie, J.H. 1991. Prinsip dan Prosedur Statistika, Suatu Pendekatan biometric. Penerbit PT Gramedia Pustaka Utama Jakarta.

Sturkie, P. D. 1976. Avian Physiology. Cornell University Press. New York.

Soeparno. 1992. Ilmu dan Teknologi Pedaging. Gajah Mada University Press. Yogyakarta. 